\title{
Front Matter: Volume 8412
}

, "Front Matter: Volume 8412," Proc. SPIE 8412, Photonics North 2012, 841201 (23 October 2012); doi: 10.1117/12.2014080

SPIE. Event: Photonics North 2012, 2012, Montréal, Canada 


\section{PROCEEDINGS OF SPIE}

\section{Photonics North 2012}

Jean-Claude Kieffer

Editor

6-8 June 2012

Montréal, Canada

Organized by

Centre d'optique, photonique et Laser, Université Laval (Canada)

CPC-Canadian Photonics Consortium (Canada)

INO-Institut National d'Optique (Canada)

Photonics North

Quebec Photonic Network (Canada)

Sponsored by

CIPI-Canadian Institute for Photonic Innovations (Canada)

CMC Microsystems (Canada)

École de technologie supérieure (Canada)

INRS (Canada)

Cooperating Organization and Publisher

SPIE 
The papers included in this volume were part of the technical conference cited on the cover and title page. Papers were selected and subject to review by the editors and conference program committee. Some conference presentations may not be available for publication. The papers published in these proceedings reflect the work and thoughts of the authors and are published herein as submitted. The publisher is not responsible for the validity of the information or for any outcomes resulting from reliance thereon.

Please use the following format to cite material from this book:

Author(s), "Title of Paper," in Photonics North 2012, edited by Jean-Claude Kieffer, Proceedings of SPIE Vol. 8412 (SPIE, Bellingham, WA, 2012) Article CID Number.

ISSN 0277-786X

ISBN 9780819490902

Published by

SPIE

P.O. Box 10, Bellingham, Washington 98227-0010 USA

Telephone +1 3606763290 (Pacific Time) · Fax +1 3606471445

SPIE.org

Copyright () 2012, Society of Photo-Optical Instrumentation Engineers

Copying of material in this book for internal or personal use, or for the internal or personal use of specific clients, beyond the fair use provisions granted by the U.S. Copyright Law is authorized by SPIE subject to payment of copying fees. The Transactional Reporting Service base fee for this volume is $\$ 18.00$ per article (or portion thereof), which should be paid directly to the Copyright Clearance Center (CCC), 222 Rosewood Drive, Danvers, MA 01923. Payment may also be made electronically through CCC Online at copyright.com. Other copying for republication, resale, advertising or promotion, or any form of systematic or multiple reproduction of any material in this book is prohibited except with permission in writing from the publisher. The CCC fee code is 0277-786X/12/\$18.00.

Printed in the United States of America.

Publication of record for individual papers is online in the SPIE Digital Library.

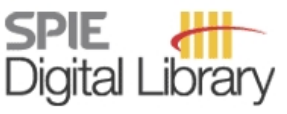

SPIEDigitalLibrary.org

Paper Numbering: Proceedings of SPIE follow an e-First publication model, with papers published first online and then in print and on CD-ROM. Papers are published as they are submitted and meet publication criteria. A unique, consistent, permanent citation identifier (CID) number is assigned to each article at the time of the first publication. Utilization of CIDs allows articles to be fully citable as soon as they are published online, and connects the same identifier to all online, print, and electronic versions of the publication. SPIE uses a six-digit CID article numbering system in which:

- The first four digits correspond to the SPIE volume number.

- The last two digits indicate publication order within the volume using a Base 36 numbering system employing both numerals and letters. These two-number sets start with 00, 01, 02, 03, 04, $05,06,07,08,09,0 A, 0 B \ldots 0 Z$, followed by 10-1Z, 20-2Z, etc.

The CID number appears on each page of the manuscript. The complete citation is used on the first page, and an abbreviated version on subsequent pages. Numbers in the index correspond to the last two digits of the six-digit CID number. 


\title{
Contents
}

\author{
xi Conference Committee \\ xiii Introduction
}

\section{BIOMEDICAL INFECTION}

841202 Maximization of signal-to-noise ratio in optical coherence tomography using a depthdependent matched filter [8412-83]

A. Boroomand, Univ. of Manitoba (Canada); M. S. D. Smith, D. P. Popescu, M. Sowa, National Research Council Canada (Canada); S. S. Sherif, Univ. of Manitoba (Canada)

841203 Tight neurovascular coupling in a rat model of quasi-periodic interictal spiking using multispectral optical imaging [8412-20]

P. Pouliot, Ecole Polytechnique de Montréal (Canada) and Montréal Heart Institute (Canada); V. T. Truong, C. Zhang, S. Dubeau, Ecole Polytechnique de Montréal (Canada);

F. Lesage, Ecole Polytechnique de Montréal (Canada) and Montréal Heart Institute (Canada)

841204 Detection of atherosclerotic vascular tissue from optical coherence tomography images [8412-7]

A. Prakash, Univ. of Manitoba (Canada); M. Hewko, M. Sowa, National Research Council

Canada (Canada); S. Sherif, Univ. of Manitoba (Canada)

841205 Development of a new method for cervical cancer cells determination using light scattering spectrum [8412-35]

Y. Yang, R. Jia, Q. Sun, Shandong Univ. (China); K. Song, B. Kong, Qilu Hospital of Shandong Univ. (China); X. SU, Shandong Univ. (China)

841206 Overview of photo-induced therapy for ATP production [8412-64]

M. Abdalla, A. Nagy, W. N. Ye, Carleton Univ. (Canada); T. Mussivand, Univ. of Ottawa Heart Institute (Canada)

841207 Speckle analysis of single cell light scattering patterns for cell classification [8412-33]

X. Sun, X. Qiao, Shandong Univ. (China); K. Song, B. Kong, Qilu Hospital of Shandong Univ. (China); X. Su, Shandong Univ. (China)

841208 Ultrasound guided fluorescence tomography [8412-56]

B. Li, F. Lesage, Ecole Polytechnique de Montréal (Canada) and Montréal Heart Institute (Canada) 
841209 A novel assay for rapid HIV-1 protease detection using optical sensors and magnetic carriers (Invited Paper) [8412-73]

C. Esseghaier, A. Ng, M. Zourob, Institut National de la Recherche Scientifique (Canada)

$8412 \mathrm{OA}$ Colorimetric assay for urinary track infection disease diagnostic on flexible substrate (Invited Paper) [8412-77]

M. Safavieh, M. U. Ahmed, M. Zourob, Institut National de la Recherche Scientifique (Canada)

8412 OB Polymeric rapid prototyping for inexpensive and portable medical diagnostics (Invited Paper) [8412-67]

T. Ma, Univ. of Waterloo (Canada); V. Northrup, Univ. of Alberta (Canada); A. O. Fung, Univ. of Waterloo (Canada); D. M. Glerum, Univ. of Waterloo (Canada) and Univ. of Alberta (Canada); C. J. Backhouse, Univ. of Waterloo (Canada)

8412 0C Biosensing using plasmonic waveguides embedded in CYTOP (Invited Paper) [8412-42] O. Krupin, P. Berini, Univ. of Ottawa (Canada)

8412 OD Selecting the appropriate splitter for a reflective optical fiber dosimeter probe [8412-32] S. Caron, A. Croteau, INO (Canada); A. Rink, D. Jaffray, Princess Margaret Hospital (Canada); O. Mermut, INO (Canada)

8412 OE High sensitivity surface enhanced Raman scattering detection of organic molecules and amino acids [8412-93]

A. Kandakkathara, I. Utkin, R. Fedosejevs, Univ. of Alberta (Canada)

8412 OF Real-time analysis of multi-laser-beam fluorescence for timed control of laser tweezers in a microfluidic cell-sorting device [8412-40]

L. M. Davis, J. L. Lubbeck, K. M. Dean, A. E. Palmer, R. Jimenez, Univ. of Colorado at Boulder (United States)

$84120 \mathrm{G}$ A new polydimethylsiloxane (PDMS) microcantilever with integrated optical waveguide for biosensing application [8412-60]

A. Sanati Nezhad, M. Ghanbari, C. G. Agudelo, M. Packirisamy, R. Bhat, Concordia Univ. (Canada)

$8412 \mathrm{OH} \quad$ Analysis of bacterial growth by UV/Vis spectroscopy and laser reflectometry [8412-75] M. C. Peña-Gomar, G. Viramontes-Gamboa, Univ. Michoacana de San Nicolás de Hidalgo (Mexico); G. Peña-Gomar, Univ. Politécnica de Chiapas (Mexico); M. Ortiz Gutiérrez, M. Hernández Ramírez, Univ. Michoacana de San Nicolás de Hidalgo (Mexico)

8412 Ol Optrodes of photonic fiber to $\mathrm{pH}$ sensor [8412-76]

A. Rendón-Romero, Univ. Michoacana de San Nicolás de Hidalgo (Mexico) and Univ. de Guanajuato (Mexico); M. Peña-Gomar, Univ. Michoacana de San Nicolás de Hidalgo (Mexico); E. Alvarado-Méndez, Univ. de Guanajuato (Mexico) 
$84120 \mathrm{~J}$ Pure surface plasmon-polariton optical sensor using an H-cross-section fiber and Bragg gratings [8412-82]

M. D. Baiad, Ecole Polytechnique de Montréal (Canada); S. M. Tripathi, Univ. du Québec en Outaouais (Canada); A. Kumar, Indian Institute of Technology Delhi (India); R. Kashyap, Ecole Polytechnique de Montréal (Canada)

\section{OPTICAL COMMUNICATIONS}

8412 OK A monolithic optical front-end for soft-decision LDPC decoders [8412-81]

M. N. Sakib, M. S. Hai, O. Liboiron-Ladouceur, McGill Univ. (Canada)

8412 OL Investigation on impact of connector scratches on 40G NRZ optical link performance [8412-16]

T. Berdinskikh, Celestica Inc. (Canada); R. Thongdaeng, V. Phunnarungsi, Celestica Inc. (Thailand); M. Gurreri, J. Webb, TE Connectivity (United States); A. Tymecki, Orange (Poland); M. Brown, JDSU Inc. (United States); G. Friedrich, Fachvorstand Energietechnik (Switzerland)

$84120 \mathrm{M}$ High-contrast germanium-doped silica-on-silicon waveguides [8412-14] P. Dumais, C. Callender, C. Blanchetière, C. Ledderhof, Communications Research Ctr. Canada (Canada)

841200 Wavelength tunable laser based on distributed reflectors with deep submicron slots [8412-80]

L. Zou, L. Wang, T. Yu, J.-J. He, Zhejiang Univ. (China)

8412 OP Dumbbell micro-ring reflector [8412-54]

H. Yun, W. Shi, X. Wang, L. Chrostowski, N. A. F. Jaeger, The Univ. of British Columbia (Canada)

$84120 Q \quad$ Constant-V step-index optical fiber with pure silica core [8412-27]

S. Tariq, Ciena Corp. (Canada); S. F. Mahmoud, Kuwait Univ. (Kuwait)

$84120 R$ Differential measurement of transmission losses of integrated optical components using waveguide ring resonators [8412-50]

W. Shi, T. K. Chang, H. Yun, W. Zhang, Y. Wang, C. Lin, N. A. F. Jaeger, L. Chrostowski, The Univ. of British Columbia (Canada)

8412 OS Impact of modulation index on transmission performance of millimeter wave multiband OFDM ultra-wide-band wireless signal over fiber system [8412-2]

M. Mohamed, Benghazi Univ. (Libyan Arab Jamahiriya); X. Zhang, B. Hraimel, Concordia Univ. (Canada); K. Wu, Ecole Polytechnique de Montréal (Canada)

8412 OT Improving transmission efficiency in optical communication [8412-41]

R. Radziwilowicz, C. Charette, Unlimi-Tech Software Inc. (Canada)

$8412 \mathrm{OU}$ Optical multiple millimeter-wave signal generation using frequency quadrupling for radioover-fiber systems [8412-3]

M. Mohamed, Univ. of Benghazi (Libyan Arab Jamahiriya); X. Zhang, Concordia Univ.

(Canada); S. Kuwairi, Univ. of Benghazi (Libyan Arab Jamahiriya) 
$84120 \mathrm{~V}$ The effect of dopant diffusion on modal birefringence in silica-on-silicon waveguides [8412-15]

P. Dumais, C. Callender, C. Ledderhof, Communications Research Ctr. Canada (Canada)

\section{CIPI PROJECTS}

$84120 \mathrm{~W}$ Gold nanostructure-integrated silica-on-silicon waveguide for the detection of antibiotics in milk and milk products [8412-70]

J. Ozhikandathil, S. Badilescu, M. Packirisamy, Concordia Univ. (Canada)

8412 0X Fabrication of surface plasmon waveguides in CYTOP [8412-39]

H. Asiri, A. Khan, E. Lisicka-Skrzek, Univ. of Ottawa (Canada); R. N. Tait, Carleton Univ. (Canada); P. Berini, Univ. of Ottawa (Canada)

8412 OY Optically interconnected high-performance servers [8412-94]

O. Liboiron-Ladouceur, M. N. Sakib, M. Sowailem, M. S. Hai, McGill Univ. (Canada);

R. Varano, D. Rolston, Reflex Photonics, Inc. (Canada)

$84120 Z$ Temperature-independent silicon waveguides comprising bridged subwavelength gratings [8412-74]

M. Ibrahim, A. Aleali, Carleton Univ. (Canada); J. H. Schmid, P. Cheben, J. Lapointe, S. Janz, P. J. Bock, A. Densmore, B. Lamontagne, R. Ma, D.-X. XU, National Research Council Canada (Canada); W. N. Ye, Carleton Univ. (Canada)

841210 Bonding of optical materials by femtosecond laser welding for aerospace and high power laser applications [8412-104]

D. Hélie, COPL, Univ. Laval (Canada); F. Lacroix, Institut Franco-Allemand de Recherches de Saint-Louis (France); R. Vallée, COPL, Univ. Laval (Canada)

841211 Laser wakefield acceleration: application to Betatron x-ray radiation production and x-ray imaging [8412-79]

S. Fourmaux, Institut National de la Recherche Scientifique (Canada); S. Corde, K. Ta Phuoc, Lab. d'Optique Appliquée, ENSTA, CNRS, École Polytechnique (France);

P. Lassonde, S. Payeur, S. Gnedyuk, F. Martin, Institut National de la Recherche Scientifique (Canada); V. Malka, A. Rousse, Lab. d'Optique Appliquée, ENSTA, CNRS, École Polytechnique (France); J. C. Kieffer, Institut National de la Recherche Scientifique (Canada)

841212 Grating coupler excitation of membrane supported long range surface plasmons [8412-17] N. R. Fong, Carleton Univ. (Canada); P. Berini, Univ. of Ottawa (Canada); R. N. Tait, Carleton Univ. (Canada)

\section{OPTICAL DESIGN AND SIMULATION}

841213 Efficient sensitivity analysis of photonic structures with transmission line modeling [8412-86] O. S. Ahmed, M. H. Bakr, McMaster Univ. (Canada); M. A. Swillam, The American Univ. in Cairo (Egypt); X. Li, McMaster Univ. (Canada) 
841214 Data encoding using periodic nanostructures [8412-51]

S. V. Grayli, S. V. Grayli, B. Omrane, C. Landrock, B. Kaminska, Simon Fraser Univ. (Canada)

841215 Highly efficient design methodology for very large scale coupled microcavities [8412-85] M. A. Swillam, The American Univ. in Cairo (Egypt); O. S. Ahmed, M. H. Bakr, X. Li, McMaster Univ. (Canada)

841216 High precision analysis of variations in self image quality and position with Multimode Interference (MMI) device width [8412-71]

T. Azfar, S. Amin, B. Malik, Air Univ. (Pakistan)

841217 Free space and waveguide Talbot effect: phase relations and planar light circuit applications [8412-30]

H. Nikkhah, Q. Zheng, I. Hasan, S. Abdul-Majid, T. J. Hall, Univ. of Ottawa (Canada)

841218 Simulation of the interaction of light and tissue in a large volume using a Markov chain Monte Carlo method [8412-59]

P. F. Pereira, S. S. Sherif, Univ. of Manitoba (Canada)

841219 Investigation of longitudinal spatial-hole burning in high-order laterally coupled distributed feedback lasers [8412-46]

A. Akrout, K. Dridi, T. J. Hall, Univ. of Ottawa (Canada)

$84121 \mathrm{~A}$ Development of an optomechanical statistical tolerancing method for cost reduction [8412-84]

F. Lamontagne, M. Doucet, INO (Canada)

8412 1B A ring resonator optical amplitude modulator using coupling control via carrier injection in the coupler [8412-61]

M. Gad, W. Shi, L. Chrostowski, N. A. F. Jaeger, The Univ. of British Columbia (Canada)

8412 1C Apodization of the incident light beam by an optimized quasi-Gaussian profile shifted along an aperture of the acousto-optical cell with appreciable acoustic losses [8412-47] A. S. Shcherbakov, Instituto Nacional de Astrofísica, Óptica y Electrónica (Mexico); A. Laskin, AdlOptica GmbH (Germany); A. V. Hanessian de la Garza, Instituto Nacional de Astrofísica, Óptica y Electrónica (Mexico)

8412 1D Study of plasmonic properties of gold nanoparticles of different shapes with emphasis on gold nanopyramids [8412-92]

A. Abumazwed, A. G. Kirk, McGill Univ. (Canada)

$84121 \mathrm{E}$ Time-bandwidth product of the acousto-optical cell based on a TeO2-crystal [8412-48] A. S. Shcherbakov, A. V. Hanessian de la Garza, V. Chavushyan, Instituto Nacional de Astrofísica, Óptica y Electrónica (Mexico); S. A. Nemov, St. Petersburg State Polytechnical Univ. (Russian Federation)

8412 IF Triple product acousto-optical processor for the astrophysical applications [8412-72] A. S. Shcherbakov, A. V. Hanessian de la Garza, V. Chavushyan, Instituto Nacional de Astrofísica, Óptica y Electrónica (Mexico); J. Campos Acosta, Consejo Superior de Investigaciones Científicas (Spain) 
$84121 \mathrm{G}$ Chemical and pressure sensors using tapered optical fiber with polymer layer [8412-13] X. Dai, H. Ding, C. Blanchetiere, S. J. Mihailov, Communications Research Ctr. Canada (Canada)

\section{GENERAL OPTICS AND PHOTONICS}

$84121 \mathrm{H} \quad$ Digital implementation of a neural network for imaging [8412-21]

R. Wood, McMaster Univ. (Canada); A. McGlashan, J. Yatulis, Niagara College (Canada);

P. Mascher, I. Bruce, McMaster Univ. (Canada)

$841211 \quad$ Single eye or camera with depth perception [8412-24]

P. Kornreich, B. Farell, Syracuse Univ. (United States)

$84121 \mathrm{~J} \quad$ Raman spectroscopy hyperspectral imager based on Bragg tunable filters [8412-18] S. Marcet, M. Verhaegen, S. Blais-Ovellette, Photon etc. (Canada); R. Martel, Univ. de Montréal (Canada)

$84121 \mathrm{~K}$ Polarization dependence compensation in transmission of chiral elements by use of a $\pi-$ shifted Sagnac loop interferometer [8412-12]

H. Exir, I. Golub, Algonquin College (Canada)

\section{GREEN ENERGY}

$84121 \mathrm{~L}$ Design of plasmonic enhanced silicon-based solar cells [8412-89]

F. Hejazi, S. Y. Ding, Y. Sun, A. Bottomley, A. Ianoul, W. N. Ye, Carleton Univ. (Canada)

$84121 \mathrm{M}$ Gold nanorods on the cathode electrode for enhancing the efficiency of polymer solar cells [8412-37]

A. Y. Mahmoud, N. Ełebari Alamdari, Concordia Univ. (Canada) and Univ. du Québec à Montréal (Canada); R. Izquierdo, Univ. du Québec à Montréal (Canada); V.-V. Truong, Concordia Univ. (Canada)

$84121 \mathrm{~N}$ Lateral diffusion epitaxy (LDE) of single crystal silicon with downward facing substrate [8412-53]

L. H. L. Yu, B. Li, H. Shen, A. H. Kitai, McMaster Univ. (Canada)

\section{LASERS AND PROCESSES}

841210 Speckle interferometry at $\mathbf{1 0} \boldsymbol{\mu \mathrm { m }}$ with $\mathrm{CO}_{2}$ lasers and microbolometers array [8412-55] M. P. Georges, J.-F. Vandenrijt, C. Thizy, Univ. de Liège (Belgium); I. Alexeenko, G. Pedrini, W. Osten, Univ. Stuttgart (Germany)

$84121 \mathrm{P} \quad$ Laser cooling with nanoparticles [8412-36] G. Nemova, E. Soares de Lima Filho, S. Loranger, R. Kashyap, Ecole Polytechnique de Montréal (Canada) 
$84121 Q \quad$ Mode-hop-free tuning of a semiconductor laser with a chirped grating in a simple extended cavity [8412-19]

D. Panneton, COPL, Univ. Laval (Canada); G. Fortin, AEREX Avionique Inc. (Canada);

N. McCarthy, COPL, Univ. Laval (Canada)

$84121 \mathrm{R} \quad 1.55 \mu \mathrm{m}$ laterally coupled ridge-waveguide DFB lasers with third-order surface grating [8412-62]

K. Dridi, A. Benhsaien, Univ. of Ottawa (Canada); J. Zhang, CMC Microsystems (Canada);

T. Hall, Univ. of Ottawa (Canada)

\section{NONLINEAR OPTICS AND PHOTONIC MATERIALS}

8412 is Recent advances in the design of photonic bandgap and hybrid fibers: from LMA to HNL fibers (Invited Paper) [8412-52]

Y. Quiquempois, A. Baz, O. Vanvincq, C. Valentin, L. Bigot, G. Bouwmans, A. Kudlinski, A. Mussot, Univ. Lille 1 (France); P. Calvet, E. Hugonnot, Commissariat à l'Energie Atomique et aux Energies Alternatives (France); M. Douay, Univ. Lille 1 (France)

$84121 \mathrm{~T} \quad$ Enhanced anisotropy of gold nanorods-polymer composite films for optical applications [8412-31]

S. Stoenescu, S. Badilescu, M. Packirisamy, V.-V. Truong, Concordia Univ. (Canada)

$84121 \mathrm{U} \quad$ Nanocrystalline GaAs thin films by pulsed laser deposition [8412-68]

F. R. Chowdhury, M. Gupta, Y. Y. Tsui, Univ. of Alberta (Canada)

$84121 \mathrm{~V} \quad$ Negative refraction characterization in one-dimensional photonic crystals [8412-58]

R. Doti, J. E. Lugo, J. Faubert, Univ. de Montréal (Canada)

$84121 \mathrm{~W} \quad$ Negative refraction in one-dimensional photonic crystals [8412-57]

J. E. Lugo, R. Doti, J. Faubert, Univ. de Montréal (Canada)

$84121 \mathrm{X} \quad$ Nonlinear optical characterization of ionics liquids of 1-methylpyrrolidine family [8412-49] M. Trejo-Duran, E. Alvarado-Mendez, E. Vargas-Rodriguez, J. M. Estudillo-Ayala,

R. I. Mata-Chavez, Univ. de Guanajuato (Mexico)

$84121 \mathrm{Y} \quad$ Physical properties study of $\mathrm{Sb}_{2} \mathrm{O}_{3}-\mathrm{PbO}-\mathrm{MnO}$ ternary system [8412-4] M. Nouadji, Univ. de Biskra (Algeria); R. El Abdi, M. Poulain, Univ. de Rennes 1 (France); A. Attaf, Univ. de Biskra (Algeria)

$841212 \quad$ SSRM and SCM study for doping concentration of THz QCL devices [8412-22]

R. S. Dhar, D. Ban, Univ. of Waterloo (Canada)

841220 Tip-enhanced Raman spectroscopy: application to the study of single silicon nanowire and functionalized gold surface (Invited Paper) [8412-5]

N. Kazemi-Zanjani, F. Pashaee, F. Lagugné-Labarthet, Univ. of Western Ontario (Canada) 
841221 Highly efficient blue organic light-emitting diodes using dual emissive layers with hostdopant system [8412-45]

B. M. Lee, McMaster Univ. (Canada); H. H. Yu, Y. H. Kim, N. H. Kim, J. A. Yoon, Hoseo Univ. (Korea, Republic of); P. Mascher, McMaster Univ. (Canada); W. Y. Kim, McMaster Univ. (Canada) and Hoseo Univ. (Korea, Republic of)

841222 A comparison of switching energy of resonant and nonresonant electro-optic switches [8412-38]

F. Soltani, A. G. Kirk, McGill Univ. (Canada)

Author Index 


\title{
Conference Committee
}

\author{
Conference Cochairs \\ Michel Têtu, Quebec Photonic Network (Canada) \\ Robert Corriveau, Canadian Institute for Photonic Innovation \\ (Canada) \\ Conference Vice Chair
}

George A. Lampropoulos, A.U.G. Signals (Canada)

Logistics and Exhibition Coordinator

Michel Walters, Conferium (Canada)

Véronique Gravel, Conferium (Canada)

Technical Program Chair

Jean-Claude Kieffer, INRS (Canada)

Session Chairs and Cochairs

Biomedical Infection

Caroline Boudoux, Chair, École Polytechnique de Montréal (Canada)

Sylvain Gioux, Beth Israel Deaconess Medical Center, Harvard Medical School (United States)

Bio-Sensors

Paul Charrette, Chair, Université de Sherbrooke (Canada)

Christopher J. Backhouse, University of Waterloo (Canada)

Pierre Berini, University of Ottawa (Canada)

Jean-François Masson, Montreal University (Canada)

Denis Boudreau, Laval University (Canada)

CIPI Projects

Robert Fedosejevs, University of Alberta (Canada)

Paul Jessop, McMaster University (Canada)

Michel Piché, Laval University (Canada)

Réal Vallée, Laval University (Canada)

Brian Wilson, Princess Margaret Hospital (Canada) 
Optical Communications

Christine Tremblay, Chair, École de Technologie Supérieure (Canada)

André Parent, National Research Council Canada (Canada)

Optical Design and Simulation

Simon Thibault, Chair, Laval University (Canada)

Min Wang, INO (Canada)

Jocelyn Parent, Immervision (Canada)

John Padzer, NRC-HIA (Canada)

Jasmin Coté, Side by Side Optics (Canada)

Nonlinear Optics and Photonic Materials

Nicolas Godbout, Chair, École Polytechnique de Montréal (Canada)

Martin Rochette, McGill University (Canada)

Roberto Morandotti, INRS-EMT (Canada)

Green Energy

Zetian Mi, Chair, McGill University (Canada)

Donald Angers, Centre of Excellence in Energy Efficiency (Canada)

John Wen, University of Waterloo (Canada)

Nate Quitoriano, McGill University (Canada)

Ultrafast Photonics and Nano-optics

François Légaré, Chair, INRS (Canada)

Andreas Ruediger, INRS (Canada)

Tsuneyuki Ozaki, INRS-ÉMT (Canada)

David M. Villeneuve, National Research Council (Canada)

Lasers and Processes

Jean-Pierre Monchalin, Chair, National Research Council Canada

(Canada)

Alain Blouin, National Research Council Canada (Canada)

General Optics and Photonics

Jean-Claude Kieffer, Chair, INRS (Canada) 


\section{Introduction}

It is with great pleasure we welcome you to the proceedings of the SPIE supported conference, Photonics North 2012, held 6-8 June 2012 in Montréal. This was yet another successful year for Photonics North, with more than 300 abstracts, attendees from 18 countries, and 40 exhibitors with a visiting delegation from China. This year's Conference drew a large audience and a very broad spectrum of research areas has been covered.

We were greatly honored to have Prof. Katarina Svanberg delivering the keynote lecture on his contributions to laser light interaction with biological tissues. The societal importance of the work on photodynamic therapy and tissue spectroscopy was obvious from her wonderful presentation.

Photonics North hosted several successful sessions including Biomedical Infection, Bio-sensors, Optical Communications, Optical Design and Simulation, Green Energy, Lasers and Processes, Nonlinear Optics, Ultrafast Photonics and Nanooptics. 70 invited speakers presented fascinating sides of optics and photonic. We were honored to have Prof. Bill Shillue from National Radio Astronomy Observatory present a plenary lecture at the banquet on the photonic technologies in the Atacama large millimeter array project. Prof. Laurent Sarger gave an illuminating plenary talk on the photonics in the Aquitaine Region in France and its impact on economic development.

These proceedings show the diversity of topics, the leading edge researches and the enabling technologies that define photonics in Canada. The world community attending the meeting reflects the relevance of the Photonics North forum as it continues to remain an important networking and scientific platform serving not only North America but also the wider photonics community.

Jean-Claude Kieffer 
Proc. of SPIE Vol. $8412841201-14$

Downloaded From: https://www.spiedigitallibrary.org/conference-proceedings-of-spie on 26 Apr 2023 Terms of Use: https://www.spiedigitallibrary.org/terms-of-use 